\title{
UJI AKTIVITAS ANTIBIOSIS PSEUDOMONADS PENDARFLUOR TERHADAP Rigidoporus lignosus (Klotszch) Imazeki PENYEBAB PENYAKIT AKAR PUTIH
}

\author{
Hasanuddin ${ }^{1}$ \\ ${ }^{1}$ Program Studi Ilmu Hama dan Penyakit Tumbuhan Fakultas Pertanian Universitas Sumatera Utara \\ Jln. Prof. A. Sofyan No.3 Medan 20155. E-mail: hasanuddiny@ yahoo.com
}

\begin{abstract}
Antibiosis activity test of fluorescent Pseudomonads against Rigidoporus lignosus (Klotszch) Imazeki the caused agent of white root disease. The potential of fluorescent bacteria as biological control agents for white root disease caused by Rigidoporus lignosus has been investigated. Isolation of bacteria from the soil using S1 media produced two fluorescent bacteria isolates. Using the Microbact 12A+12B method, both bacteria were identified as Pseudomonas fluorescens and $P$. aeruginosa. These two species of bacteria were then used as antibiosis activity test against $R$. lignosus. Four series antibiosis activity tests were done, that were antibiosis test of media culture bacteria growth to $R$. lignosus colony, antibiosis test of dry fluorescent pigment extract to $R$. lignosus, influence of $\mathrm{Fe}^{3+}$ to antibiosis activity of bacteria test, and affinity of media supernatant to $\mathrm{Fe}^{3+}$. The results were: antibiosis activity of King's B (KB) media was more effective than media 523 in the inhibition of $R$. lignosus colony growth. There was no significant different antibiosis activity of dry fluorescent pigment extract from media KB and media 523 in the inhibition of $R$. lignosus colony growth. The level of $\mathrm{Fe}^{3+}$ in the media might influence antibiosis activity of fluorescent pigment. Affinity test of $\mathrm{KB}$ supernatant from fluorescent bacteria culture with $\mathrm{Fe}^{3+}$ showed an absorption peak of $410 \mathrm{~nm}$ on spectrophotometer, and none for the fungi. These results indicate that $P$. fluorescens and $P$. aeruginosa produce cathecol-type siderophore with high affinity against $\mathrm{Fe}^{3+}$ compared with hydroxamate-type siderophore which is generally produced by fungus.
\end{abstract}

Keywords: Biological control, Rigidoporus lignosus, Pseudomonas fluorescens, P. aeruginosa, antibiosis activity

\begin{abstract}
ABSTRAK
Uji aktivitas antibiosis Pseudomonads pendarfluor terhadap Rigidoporus lignosus (Klotszch) Imazeki penyebab penyakit akar putih. Kajian potensi bakteri pendarfluor sebagai agens hayati pengendalian Rigidoporus lignosus penyebab penyakit akar putih telah dilakukan. Isolasi bakteri menggunakan media S1 telah mendapatkan dua isolat bakteri pendarfluor. Dengan metode Microbact 12A + 12B, kedua bakteri teridentifikasi sebagai Pseudomonas fluorescens dan P. aeruginosa. Kedua jenis bakteri ini selanjutnya digunakan sebagai bakteri uji aktivitas antibiosis terhadap R. lignosus. Empat seri uji aktivitas antibiosis dilakukan untuk itu yaitu uji antibiosis media pembiakan bakteri terhadap koloni $R$. lignosus, uji antibiosis ekstrak kering pigmen pendarfluor terhadap koloni $R$. lignosus, pengaruh $\mathrm{Fe}^{3+}$ terhadap aktivitas antibiosis bakteri uji, dan affinitas supernatan media terhadap unsur $\mathrm{Fe}^{3+}$. Hasil kajian menunjukkan bahwa media King's B (KB) lebih efektif dari pada media 523 dalam menekan pertumbuhan koloni R. lignosus. Aktivitas antibiosis dari ekstrak kering media KB dan media 523 berbeda tidak nyata dalam menekan pertumbuhan koloni $R$. lignosus. Kadar $\mathrm{Fe}^{3+}$ dalam media dapat mempengaruhi aktivitas antibiosis pigmen pendarfluor. Uji affinitas supernatan media pembiakan $P$. fluorescens dan $P$. aeruginosa terhadap $\mathrm{Fe}^{3+}$ menunjukkan bahwa puncak absorbansi spektrofotometer terbaca pada panjang gelombang $410 \mathrm{~nm}$. Hasil ini menunjukkan bahwa $P$. fluorescens dan $P$. aeruginosa menghasilkan siderofor dari golongan katekol yang affinitasnya lebih tinggi dibandingkan siderofor golongan hidraksamat yang umumnya dihasilkan jamur.
\end{abstract}

Kata kunci : Pengendalian biologi, Rigidoporus lignosus, Pseudomonas fluorescens, $P$. aeruginosa, aktivitas antibiosis

\section{PENDAHULUAN}

Rigidoporus lignosus (Klotszch) Imazeki adalah jamur saprofit penghuni tanah. Jamur ini dapat bertahan dalam tanah dengan membentuk rizomorf. Jika bertemu dengan akar tanaman akan berubah menjadi parasit dan menyebabkan penyakit akar putih pada beberapa jenis tanaman. Sekali tanah terkontaminasi oleh $R$. lignosus seterusnya tanah akan dihuni oleh jamur tersebut dan menjadi ancaman untuk setiap penanaman baru. Peremajaan yang berulang-ulang akan menyebabkan akumulasi sumber penyakit akar putih dalam tanah (Basuki, 1985). 
Pseudomonas spp, termasuk jenis bakteri aerobik, gram-negatif, beberapa jenis diantaranya mengeluarkan pigmen pendarfluor secara ekstraselluler, satu spesies diantaranya adalah $P$. fluorescens. Bakteri ini dijumpai hampir disemua jenis lahan pertanian dan mempunyai beberapa ciri yang membuatnya sesuai sebagai agen pengendalian hayati penyakit tumbuhan terbawa tanah dan nematode (Weller, 2007). Sehubungan dengan kemampuannya sebagai agen pengendalian hayati, $P$. fluorescens telah dikaji selama beberapa dekade dan sudah diformulasi dan terdaftar sebagai produk komersial di U.S. Environmental Protection Agency sebagai agen pengendalian hayati penyakit tumbuhan (Stockwell \& Stack, 2007).

Ciri utama $P$. fluorescens yang membuatnya sesuai sebagai agen pengendalian hayati penyakit tumbuhan yang dapat dikomersilkan antara lain; (i) tumbuh dengan cepat pada sediaan in-vitro untuk produksi missal, (ii) dengan cepat dapat memanfaatkan eksudat akar di persemaian, (iii) dapat membentuk koloni dan penggandaannya di lingkungan rizosfir, spermosfir dan interior tanaman, (iv) menghasilkan pigmen pendarfluor yang manjadi bahan baku bioaktif berspektrum lebar (misalnya, antibiotik, siderofor, senyawa volatil, dan fitohormon), (v) bersaing agresif dengan mikroorganisme lain, (vi) mampu menyesuaikan diri terhadap tekanan lingkungan, dan (vii) memiliki keupayaan genetik yang mendukung kompetensi sebagai agensia hayati (Humphris et al., 2005; Weller, 2007).

Kelompok Pseudomonas penghasil pigmen pendarfluor ini disebut sebagai kelompok Pseudomonads pendarfluor. Diantara spesies yang termasuk dalam Pseudomonads pendarfluor adalah $P$. aeruginosa, $P$. fluorescens, $P$. ovalis, $P$. mildenbergii, $P$. reptilivora, $P$. geniculata, dam $P$. calciprecipitans (Meyer \& Abdallah, 1978).

P. fluorescens juga berperan sebagai agen suppressive alami terhadap penyakit tumbuhan terbawa tanah pada beberapa lahan, yaitu suatu fenomena berkurangnya kejadian infeksi penyakit tanaman pada lahan yang ditanam tumbuhan sejenis secara terus menerus. Diduga hal ini terjadi karena hasil metabolit bakteri tersebut yang dikeluarkan ke lingkungan akar (Stutz et al., 1986). Kelemahan utama jenis bakteri $P$. fluorescens sebagai agen pengendalian hayati adalah ketidak-mampuan untuk menghasilkan struktur dorman seperti Bacillus spp., dan ini mempersulit formulasi bakteri untuk sediaan komersial (Weller et al., 2002).

Pseudomonas spp. mengeluarkan antibiotik 2,4diacetlyphloroglucinol (DAPG) yang dapat menekan aneka patogen terbawa tanah, dan dipercayai telah berkontribusi pada beberapa kasus penyakit tanaman yang gagal berkembang pada jenis tanah tertentu (Weller et al., 2002). Beberapa strain bakteri rizosfir mengeluarkan asam salisilik dalam lingkungan yang kahat unsur besi. Asam salisilik ini berkontribusi pada induksi ketahanan tanaman terhadap infeksi penyakit (Raaijmakers et al., 2006).

Kajian lain menunjukkan bahwa mayoritas bakteri mengeluarkan siderofor, yaitu suatu senyawa bersifat kelat yang berupaya kuat mengikat besi (affinitas terhadap besi) sebagai respon limitasi besi (Barton \& Hemming, 1993 dalam Press et al., 2001). Diantara siderofor yang dikeluarkan oleh bakteri rizosfir, hanya pyoverdines (juga disebut pseudobactins) yang dikeluarkan oleh $P$. fluorescens yang berimplikasi terhadap ketahanan terimbas (Duijff et al., 1994).

Tujuan penelitian ini untuk mengetahui aktivitas antagonis bakteri Pseudomonads pendarfluor terhadap patogen $R$. lignosus melalui uji in-vitro antibiosis pigmen pendarfluor, pengaruh kadar $\mathrm{Fe}^{3+}$ media pada aktivitas antibiosis, dan uji affinitas pigmen pendarfluor terhadap unsur $\mathrm{Fe}^{3+}$. Uji in-vitro antibiosis pigmen pendarfluor bertujuan untuk mengetahui apakah bakteri uji mengeluarkan pigmen pendarfluor yang dapat menghambat pertumbuhan koloni $R$. lignosus. Uji pengaruh kadar $\mathrm{Fe}^{3+}$ media dilakukan untuk mengetahui apakah aktivitas antibiosis bakteri pendarfluor terkait dengan pengeluaran siderofor. Uji affinitas pigmen pendarfluor dilakukan untuk mengetahui jenis siderofor yang dihasilkan bakteri pendarfluor dan kemampuannya mengikat unsur $\mathrm{Fe}^{3+}$.

\section{METODE PENELITIAN}

Penelitan ini dilaksanakan di Laboratorium Penyakit Tumbuhan Fakultas Pertanian USU pada bulan Januari sampai dengan Mei 2009.

Seleksi Bakteri Pendarfluor. Bakteri diisolasi dari tanah hutan konservasi Taman Hutan Raya (TAHURA) di Kabupaten Karo, Sumatera Utara, menggunakan media selektif S1 (Gould et al. 1985). Bahan media S1 per liter adalah $18 \mathrm{~g}$ agar, $10 \mathrm{~g}$ sukrosa, $10 \mathrm{ml}$ gliserol, $5.0 \mathrm{~g}$ asam kasamino (Difco), $1.0 \mathrm{~g} \mathrm{NaHCO}_{3}, 1.0 \mathrm{~g}$ $\mathrm{MgSO}_{4} \cdot 7 \mathrm{H}_{2} \mathrm{O}, 2.3 \mathrm{~g} \mathrm{~K}_{2} \mathrm{HPO}_{4}, 1.2 \mathrm{~g}$ natrium lauroyl sarkosina, dan $20 \mathrm{mg}$ Trimethoprim (Sigma). Trimethoprim disteril dengan membran filter pori $0.4 \mathrm{~m}$ (Advantec MFS) dan dicampur dengan media pada suhu $40-45^{\circ}$ C. Media S1 diatur pada $\mathrm{pH}$ 7.4-7.6. Media disimpan 2 hari pada suhu kamar sebelum digunakan. Bakteri yang menunjukkan ciri pendarfluor pada media isolasi kemudian dimurnikan. Isolat bakteri pendarfluor selanjutnya diidentifikasi dengan uji karakterisasi 
fisiologis dan reaksi biokimia memakai sistem Microbact $12 \mathrm{~A}+12 \mathrm{~B}$ ditambah uji oksidase dan motiliti.

Uji Antibiosis Supernatan Media Pembiakan Bakteri terhadap Koloni $\boldsymbol{R}$. lignosus. Uji antibiosis supernatan media pembiakan bakteri dilakukan dengan mengambil supernatan media yang digunakan yaitu media King's B (King et al., 1954 dalam Goszczynska et al., 2007) dan media 523 (Kado dan Heskett, 1970). Bakteri uji dibiakkan dalam $150 \mathrm{ml}$ media dalam erlenmeyer $250 \mathrm{ml}$. Kandungan media King'B (KB) per liter adalah $20 \mathrm{~g}$ proteus pepton, $10 \mathrm{~g}$ gliserol, $1,5 \mathrm{~g}$ $\mathrm{K}_{2} \mathrm{HPO}_{4}, 1,5 \mathrm{~g} \mathrm{MgSO}_{4}$, media $\mathrm{KB}$ diatur pada $\mathrm{pH} 7,2$. Kandungan media 523 per liter adalah $10 \mathrm{~g}$ sukrosa, $8 \mathrm{~g}$ kasein hidrolisat, $4 \mathrm{~g}$ yis ekstrak, $2 \mathrm{~g} \mathrm{~K}_{2} \mathrm{HPO}_{4}, 0,3 \mathrm{~g}$ $\mathrm{MgSO}_{4} \cdot 7 \mathrm{H}_{2} \mathrm{O}$, media 523 diatur pada $\mathrm{pH}$ 6,9 setelah disterilkan. Biakan bakteri dikocok dengan pengocok orbital pada kecepatan $150 \mathrm{rpm}$ selama 6 hari pembiakan. Selanjutnya media disentrifugasi menggunakan rotor SS-34 dengan kecepatan $12.000 \mathrm{~g}$ (Sorvall RC-5B) selama 10 menit pada suhu $23^{\circ} \mathrm{C}$. Supernatan dikumpulkan dan disteril dengan membran filter ukuran pori $0.4 \mathrm{~mm}$ dan $0.2 \mathrm{~mm}$ (Millipore) secara berurut. Uji antibiosis dilakukan dengan mencampurkan supernatan steril dengan media PDA yang masih cair (suhu $35-40^{\circ} \mathrm{C}$ ) dalam botol universal masing-masing dengan kadar 0 (kontrol), 20, 30, 40, $50 \mathrm{ml}$ per ml PDA. Campuran PDA dan supernatan steril dituang ke dalam cawan petri diameter $9 \mathrm{~cm}$ dan dibiarkan dalam suhu kamar selama satu malam. Satu bor gabus (diameter 5 $\mathrm{mm}$ ) jamur $R$. lignosus dari biakan berumur 8 hari diinokulasikan di tengah media dalam cawan petri. Pengujian dilakukan dengan rancangan acak lengkap dengan 3 ulangan, setiap ulangan terdiri dari 2 cawan petri. Diameter koloni diukur pada hari ke 8 setelah inokulasi.

Ekstraksi Pigmen Pendarfluor. Ekstraksi pigmen pendarfluor dari media pertumbuhan bakteri pendarfluor dilakukan menurut metode Powell et al., (2000) dan Cui \& Harling (2006) yang dimodifikasi. Isolat bakteri dibiakkan dalam media KB cair dan media 523 cair untuk mendapatkan ekstrak pigmen pendarflour. Suspensi biakan bakteri 6 hari setelah inokulasi disentrifugasi dengan rotor SS-34 dengan kecepatan $7.000 \mathrm{~g}$ (Sorvall RC-5B) selama 15 menit pada suhu $23^{\circ} \mathrm{C}$. Supernatant diambil dan diturunkan pH-nya sampai 2 dengan menambahkan HCL $1 \mathrm{M}$ kemudian ditambah etil asetat dengan perbandingan 1:5 dan larutan dimasukkan dalam corong pemisah dan dikocok 1-2 menit. Lapisan etil asetat yang terpisah dikumpulkan dan dipekatkan dengan evaporator. Ekstrak pigmen pendarfluor dalam labu evaporator dilarutkan dengan methanol kemudian dikeringkan dalam desikator. Hasil estraksi pigmen pendarfluor kering disimpan dalam desikator sebelum digunakan.

Uji Antibiosis Ekstrak Kering Pigmen Pendarfluor terhadap Koloni $\boldsymbol{R}$. lignosus. Uji ekstrak kering pigmen pendarfluor dilakukan untuk mengetahui aktivitas antibiosis ekstrak kering dari media biakan bakteri yang menampung pigmen pendarfluor yang dihasilkan bakteri. Uji aktivitas antibiosis dilakukan terhadap koloni jamur $R$. lignosus. Sebanyak 100 mg ekstrak kering dilarutkan dalam 1,0 ml aseton 50\%. Kadar ekstrak kering pigmen pendarfluor dalam media PDA yang diuji adalah 0,5, $1,0,2,5,5,0,7,5$, dan $10,0 \mathrm{mg} / \mathrm{ml}$ PDA. Untuk perlakuan kontrol positif adalah campuran PDA dengan aseton $50 \%$ sesuai dengan volume pelarut yang ditambahkan untuk perlakuan kadar ekstrak kering. Kontrol negatif adalah media PDA yang ditambah $1 \mathrm{ml}$ air suling steril. Media uji di atas dibiarkan selama $3 \times 24$ jam agar pelarut aseton menguap. Jamur $R$. lignosus dari kultur berumur 8 hari diinokulasikan satu propagul (bor gabus diameter $5 \mathrm{~mm}$ ) di tengah media dalam cawan petri berdiameter $9 \mathrm{~cm}$. Pengujian dilakukan dengan rancangan acak lengkap dengan 3 ulangan. Setiap ulangan terdiri dari 2 cawan petri. Diameter koloni diukur pada hari ke 7 setelah inokulasi.

Pengaruh $\mathrm{Fe}^{3+}$ terhadap Aktivitas Antibiosis Bakteri Pseudomonads Pendarfluor. Pengujian pengaruh $\mathrm{Fe}^{3+}$ terhadap aktivitas antibiosis isolat bakteri dilakukan menurut metode Temple et al., (2004) yang dimodifikasi. Bakteri Pseudomonads pendarfluor dikulturkan dalam media KB selama 6 hari. Suspensi biakan bakteri disentrifugasi menggunakan rotor SS-34 dengan kecepatan $12.000 \mathrm{~g}$ (Sorvall RC-5B) selama 10 menit pada suhu $23^{\circ} \mathrm{C}$. Supernatan dikumpulkan dan disteril dengan membran filter pori $0.4 \mathrm{~mm}$ dan $0.2 \mathrm{~mm}$ (Millipore). Media PDA sebagai media percobaan ditambah $\mathrm{Fe}^{3+}$ steril dengan kadar 0, 10, 25, 50, 100, 250, 500, 1000, dan $2500 \mathrm{mg} / \mathrm{l}$ PDA, kemudian ditambah dengan supernatant yang telah steril di atas sebanyak $50 \mathrm{ml} / \mathrm{ml} \mathrm{PDA}\left(\mathrm{FeCl}_{3}\right.$ dilarutkan dengan air suling dan disterilkan dengan membran filter pori $0.2 \mathrm{~mm}$ ). Sebagai kontrol media PDA tidak diperlakukan dengan supernatant dan $\mathrm{Fe}^{3+}$. Masing-masing media dengan perlakuan di atas dituang ke dalam cawan petri diameter $9 \mathrm{~cm}$ kemudian pada bagian tengah diinokulasi satu propagul miselium $R$. lignosus yang diambil menggunakan bor gabur diameter $5 \mathrm{~cm}$ dari kultur jamur berumur 8 hari. Pengujian dilakukan dengan rancangan acak lengkap dengan 3 ulangan. Tiap-tiap ulangan terdiri 
dari 2 cawan petri. Diameter koloni diukur pada hari ke 8 setelah inokulasi.

Affinitas Supernatan Media terhadap Unsur $\mathrm{Fe}^{3+}$. Affinitas pada unsur $\mathrm{Fe}^{3+}$ berarti kemampuan senyawa yang bersifat kelat mengikat $\mathrm{Fe}^{3+}$ jika unsur tersebut tersedia dalam jumlah yang terbatas (kahat besi). Pengujian affinitas supernatan media dilakukan menurut metode Scher \& Baker (1982), dimana bakteri $P$. fluorescens, $P$. aeruginosa dan jamur $R$. lignosus masing-masing dibiakkan dalam media KB. Dari kajian ini akan diketahui jenis dan kemampuan siderofor yang dihasilkan bakteri dan jamur patogen sebagai bahan kelat yang mengikat $\mathrm{Fe}^{3+}$. Pengamatan jenis dan kemampuan siderofor tersebut dapat dikenal melalui panjang gelombang puncak absorbansi pada spektrofotometer.

Sebanyak $0,01 \mathrm{ml}$ bakteri dibiakkan dalam $50 \mathrm{ml}$ media dan dikocok di atas pengocok orbital selama 5 hari pada suhu $25 \pm 1^{0} \mathrm{C}$. Sebanyak 5 propagul (bor gabus diameter $5 \mathrm{~mm}$ ) $R$. lignosus dibiakkan ke dalam $150 \mathrm{ml}$ media dan dikocok di atas pengocok orbital selama 5 hari. Setelah cukup masa pembiakan bakteri dan jamur, masing-masing suspensi biakan disentrifugasi dengan rotor SS-34 pada kecepatan $2500 \mathrm{~g}$ (Sorvall RC5B) selama 10 menit pada suhu $23^{\circ} \mathrm{C}$. Supernatan disterilkan dengan membran filter $0.4 \mathrm{~mm}$ (Millipore). Supernatan steril ditetesi dengan $1 \mathrm{M} \mathrm{HCl}$ untuk mencapai keasaman pH 5.5. Supernatan steril kemudian dimasukkan kedalam 2 tabung spektrofotometer masingmasing sebanyak $3 \mathrm{ml}$. Satu tabung ditambah $0.015 \mathrm{ml}$ $10^{-2} \mathrm{M} \mathrm{FeCl}_{3}$, sedangkan tabung yang lain sebagai kontrol tidak ditambah $\mathrm{FeCl}_{3}$. Uji absorbansi spektrofotometer dibaca mulai dari panjang gelombang $350 \mathrm{~nm}$ sampai
$500 \mathrm{~nm}$ (Bausch Lomb Spectronic 20 spectrophotometer).

\section{HASIL DAN PEMBAHASAN}

Isolat Bakteri Pendarfluor. Dua isolat bakteri hasil isolasi yang menunjukkan pigmen pendarfluor hijaukekuningan pada media S1 dimurnikan dan diperbanyak mengunakan media agar nutrien (Difco). Uji karakterisasi fisiologis dan reaksi biokimia dengan sistem Microbact 12A + 12B ditambah uji oksidase dan motiliti menunjukkan kedua jenis bakteri pendarfluor tersebut adalah $P$. fluorescens dan $P$. aeruginosa. Spesies bakteri inilah yang digunakan untuk pengujian selanjutnya.

Antibiosis Supernatan Media Pembiakan Bakteri terhadap Koloni $\boldsymbol{R}$. lignosus. Hasil pengamatan menunjukkan bahwa antibiosis supernatan media KB dari pembiakan $P$. fluorescens dan $P$. aeruginosa lebih kuat menekan pertumbuhan koloni miselium $R$. lignosus dibandingkan antibiosis supernatan dari media 523. Analisis statistik menunjukkan bahwa antibiosis supernatan media KB dari kedua isolat bakteri pada kadar $20 \mathrm{ml} / \mathrm{ml}$ lebih kuat menekan pertumbuhan koloni $R$. lignosus daripada supernatan media 523 pada kadar $50 \mathrm{ml} / \mathrm{ml}$. Tabel 1 di bawah ini menunjukkan aktivitas antibiosis supernatan media KB dan media 523 terhadap pertumbuhan koloni $R$. lignosus.

Bakteri $P$. fluorescens dan $P$. aeruginosa termasuk diantara bakteri pengeluar pigmen pendarfluor bersifat antibiosis yang dapat dipanen dari media pembiakannya (Mavrodi et al., 2007). Strains

Tabel 1. Diameter pertumbuhan koloni jamur R. lignosus $(\mathrm{mm})$ pada media PDA dengan perlakuan supernatan media pembiakan bakteri $P$. fluorescens dan $P$. aeruginosa dengan tingkat konsentrasi berbeda ( 8 hari setelah inokulasi)

\begin{tabular}{lcccc}
\hline $\begin{array}{c}\text { Asal Supernatan } \\
\text { (Jenis bakteri dan media } \\
\text { pertu mbuhan) }\end{array}$ & $\begin{array}{c}\text { Supernatan } \\
20 \mu 1 / \mathrm{ml}\end{array}$ & $\begin{array}{c}\text { Supernatan } \\
30 \mu 1 / \mathrm{ml}\end{array}$ & $\begin{array}{c}\text { Supernatan } \\
40 \mu 1 / \mathrm{ml}\end{array}$ & $\begin{array}{c}\text { Supernatan } \\
50 \mu 1 / \mathrm{ml}\end{array}$ \\
\cline { 2 - 5 } & $34,17 \mathrm{~b}^{(*}$ & $30,17 \mathrm{c}$ & $24,83 \mathrm{c}$ & $22,17 \mathrm{c}$ \\
P. fluorescens + Media KB & $64,83 \mathrm{a}$ & $56,83 \mathrm{~b}$ & $56,00 \mathrm{~b}$ & $55,00 \mathrm{~b}$ \\
P. fluorescens + Media 523 & $36,83 \mathrm{~b}$ & $32,83 \mathrm{c}$ & $31,17 \mathrm{c}$ & $23,83 \mathrm{c}$ \\
P. aeruginosa + Media KB & $65,00 \mathrm{a}$ & $59,17 \mathrm{~b}$ & $55,00 \mathrm{~b}$ & $53,17 \mathrm{~b}$ \\
P. aeruginosa + Media 523 & $68,00 \mathrm{a}$ & $68,00 \mathrm{a}$ & $68,00 \mathrm{a}$ & $68,00 \mathrm{a}$ \\
Kontrol & & & & \\
\hline
\end{tabular}

Keterangan :

$\left(^{*}=\right.$ Huruf yang sama pada kolom yang sama menunjukkan berbeda tidak nyata berdasarkan uji beda nyata Duncan pada taraf $5 \%$.

Kontrol = Penambahan media PDA dengan air suling steril dengan kon sentrasi yang sama dengan penambahan konsentrasi supernatan. 
Pseudomonas spp. pendarfluor secara ekstensif telah dikaji sebagai agen pengendalian hayati dan kesemuanya mengeluarkan senyawa antibiotik larut air seperti turunan fenazin, pyoluteorin, pyrrolnitrin, oomycin A, viscosinamide, dan 2,4-diacetylphloroglucinol (Michel et al., 2005). 2,4-DAPG keluaran strain Pseudomonas fluorescens aktif melawan bakteri fitopatogenik, jamur, oomycetes, dan nematode. Hasil purifikasi 2,4-DAPG dapat berfungsi sebagai antiviral, antibakterial, antijamur, dan memperkaya fitotoksik (Haas dan Défago, 2005). Cara kerja dari 2,4-DAPG melawan fitopatogen belum dapat dijelaskan sepenuhnya, tetapi terhadap Pythium spp. diduga telah menyebabkan kerusakan pada membran sel dan zoospora (de Souza et al., 2003).

Antibiosis Ekstrak Kering Pigmen Pendarfluor terhadap Koloni $\boldsymbol{R}$. lignosus. Hasil uji statistik menunjukkan bahwa ekstrak kering pigmen pendarfluor dari kedua jenis bakteri dan kedua jenis media pembiakan bakteri berbeda nyata dibandingkan kontrol. Aktivitas antibiosis ekstrak kering terhadap koloni $R$. Lignosus sudah menunjukkan efektifitasnya dari kadar yang paling rendah pada pengujian ini yaitu $0,5 \mathrm{mg} / \mathrm{ml}$. Analisis statistik pengaruh perlakuan ekstrak kering pigmen pendarfluor dari bakteri $P$. fluorescens dan $P$. aeruginosa disajikan dalam Tabel 2.

Meskipun antibiosis ekstrak kering pigmen pendarfluor masing-masing bakteri dari media 523 dan media KB pada kadar yang sama berdasarkan hasil analisis statistik menunjukkan aktivitas berbeda tidak nyata, namun dalam penelitian ini untuk memperoleh ekstrak kering diperlukan volume media 523 yang lebih banyak daripada media $\mathrm{KB}$, ini menunjukkan bahwa penggunaan media $\mathrm{KB}$ sebagai penghasil pigmen pendarfluor yang bersifat antibiosis terhadap $R$. Lignosus lebih efektif dibandingkan medium 523.

Pengaruh $\mathrm{Fe}^{3+}$ terhadap Aktivitas Antibiosis $P$. fluorescens dan $P$. aeruginosa. Hasil pengujian menunjukkan bahwa supernatan dari kedua jenis bakteri akan berkurang aktivitas antibiosisnya terhadap jamur bila unsur $\mathrm{Fe}^{3+}$ mencapai kadar tertentu dalam PDA. Semakin kecil kadar $\mathrm{Fe}^{3+}$ dalam media PDA (100 sampai dengan $0 \mathrm{~g} / \mathrm{l}$ ), aktivitas antibiosis supernatan media pembiakan bakteri semakin kuat menekan pertumbuhan koloni $R$. lignosus. Pada kadar $\mathrm{Fe}^{3+} 250$ sampai dengan $1.000 \mathrm{mg} / \mathrm{l} \mathrm{PDA}$ aktivitas antibiosis mencapai optimum. Pada kadar $\mathrm{Fe}^{3+} 2.500 \mathrm{mg} / \mathrm{l}$ aktivitas antibiosis menurun,

Tabel 2. Pengaruh perlakuan ekstrak kering pigmen pendarfluor dari bakteri $P$. fluorescens dan $P$. aeruginosa terhadap pertumbuhan koloni $R$. lignosus pada media PDA 7 hari setelah inoku lasi

\begin{tabular}{|c|c|c|}
\hline \multirow{3}{*}{$\begin{array}{c}\text { Kadar ekstrak kering dari } \\
\text { media KB dan } 523 \\
(\mu \mathrm{g} / \mathrm{ml} \text { PDA })\end{array}$} & \multicolumn{2}{|c|}{ Diameter koloni $(\mathrm{mm})^{a}$} \\
\hline & \multicolumn{2}{|c|}{ Asal ekstrak biakan bakteri } \\
\hline & P. fluorescens & P. aeruginosa \\
\hline Media 523 & & \\
\hline 0,5 & $64,00 \mathrm{~b}^{*)}$ & $59,67 \mathrm{~b}$ \\
\hline 1,0 & $56,00 \mathrm{c}$ & $54,67 \mathrm{bc}$ \\
\hline 2,5 & $48,00 \mathrm{de}$ & $43,00 \mathrm{~d}$ \\
\hline 5,0 & $42,33 \mathrm{fg}$ & 35,00 ef \\
\hline 7,5 & $38,67 \mathrm{gh}$ & $30,67 \mathrm{f}$ \\
\hline 10,0 & $36,67 \mathrm{~h}$ & $30,33 \mathrm{f}$ \\
\hline Media KB & & \\
\hline 0,5 & $56,33 \mathrm{c}$ & $53,67 \mathrm{c}$ \\
\hline 1,0 & $51,33 \mathrm{~cd}$ & $50,67 \mathrm{c}$ \\
\hline 2,5 & 45,33 ef & $38,00 \mathrm{de}$ \\
\hline 5,0 & $39,67 \mathrm{gh}$ & 35,00 ef \\
\hline 7,5 & $39,33 \mathrm{gh}$ & 31,83 ef \\
\hline 10,0 & $36,00 \mathrm{~h}$ & $29,17 \mathrm{f}$ \\
\hline Kontrol + & $71.67 \mathrm{a}$ & $71.67 \mathrm{a}$ \\
\hline Kontrol - & $67.00 \mathrm{ab}$ & $67.0 \mathrm{ab}$ \\
\hline
\end{tabular}

a) Rerata dari 3 ulangan,

*) huruf yang sama pada kolom yang sama berarti perlakuan berbeda tidak nyata berdasarkan uji jarak ganda Duncan's pada taraf 5\%. 
diduga ini terjadi karena kadar $\mathrm{Fe}^{3+}$ telah melewati batas normal sehingga menghambat pertumbuhan koloni jamur. Hasil analisis statistik pengaruh $\mathrm{Fe}^{3+}$ terhadap aktivitas antibiosis $P$. fluorescens dan $P$. aeruginosa disajikan dalam Tabel 3. puncak absorbansi dari supernatan media pertumbuhan R. lignosus (Gambar 1).

Menurut Teintze et al., (1981) dan Scher \& Baker (1982) jika puncak absorbansi terbaca pada panjang gelombang $410 \mathrm{~nm}$ menunjukkan bahwa

Tabel 3. Pengaruh kadar $\mathrm{Fe}^{3+}$ dalam PDA terhadap aktivitas antibiosis supernatan media $\mathrm{KB}$ dari pengkulturan $P$. fluorescens dan $P$. aeruginosa

\begin{tabular}{ccc}
\hline \multirow{3}{*}{ Kadar Fe $^{3+}$ dalam PDA $(\mu \mathrm{g} / \mathrm{l})$} & \multicolumn{2}{c}{ Diameter koloni $R$. lignosus $(\mathrm{mm})^{a}$} \\
\cline { 2 - 3 } & \multicolumn{2}{c}{ Asal supernatant } \\
\cline { 2 - 3 } & P. fluorescens $^{2}$ aeruginosa \\
\hline 0 & $22,33 \mathrm{e}$ & $22,66 \mathrm{~g}$ \\
10 & $22,33 \mathrm{e}$ & $30,00 \mathrm{f}$ \\
50 & $23,83 \mathrm{e}$ & $32,17 \mathrm{ef}$ \\
100 & $36,17 \mathrm{~cd}$ & $34,17 \mathrm{e}$ \\
250 & $40,00 \mathrm{bc}$ & $39,33 \mathrm{~d}$ \\
500 & $45,33 \mathrm{~b}$ & $45,17 \mathrm{c}$ \\
1.000 & $44,83 \mathrm{~b}$ & $48,33 \mathrm{bc}$ \\
2.500 & $42,83 \mathrm{~b}$ & $49,17 \mathrm{~b}$ \\
Kontrol $^{\mathrm{b}}$ & $32,17 \mathrm{~d}$ & $32,33 \mathrm{ef}$ \\
& $68,33 \mathrm{a}$ & $68,33 \mathrm{a}$ \\
\hline
\end{tabular}

Keterangan :

a) Huruf yang sama pada kolom yang sama berarti perlakuan berbeda tidak ny ata berdasarkan uji jarak ganda Duncan's pada taraf $5 \%$.

b) Media PDA tanpa penambahan $\mathrm{Fe}^{3+}$ dan supernatan media biakan bakteri.

Di bawah kondisi kahat besi, mikroba menghasilkan bahan kelat yang disebut siderofor yang dapat mengikat unsur besi dan sesudah itu mengangkutnya ke dalam sel mikroba (Jean-Marie et al., 2002). Pada kondisi kahat besi tersebut $P$. fluorescens WCS374 menghasilkan siderofor pseudobactin pendarfluor, asam salisil, dan pseudomonine yaitu sejenis siderofor yang mengandung sebagian asam salisil. Sedangkan $P$. aeruginosa mengeluarkan pyochelin, yaitu siderofor yang dapat mengikat $\mathrm{Mo}^{4+}, \mathrm{Co}^{2+}$, dan $\mathrm{Fe}^{3+}$ (Sebat et al., 2001). Hasil kajian menunjukkan bahwa antibiosis supernatan media pembiakan bakteri uji terhadap pertumbuhan koloni jamur $R$. lignosus dipengaruhi oleh kadar besi, ini menunjukkan bahwa supernatan media pembiakan bakteri merupakan bahan kelat yang mekanisme kerjanya dipengaruhi kesediaan unsur besi.

Affinitas Supernatan Media terhadap Unsur $\mathrm{Fe}^{3+}$. Hasil pengujian affinitas terhadap unsur $\mathrm{Fe}^{3+}$ dengan spektrofotometer menunjukkan bahwa puncak absorbansi pigmen pendarfluor dari supernatan media pembiakan $P$. fluorescens dan $P$. aeruginosa terbaca pada panjang gelombang $410 \mathrm{~nm}$, dan tidak ditemukan siderofor yang dihasilkan dari golongan katekol. Menurut Neilands \& Leong (1986) siderofor dari golongan katekol lebih kuat affinitasnya terhadap unsur besi dari pada siderofor golongan hidroksamat yaitu siderofor yang umumnya dihasilkan oleh jamur. Hasil kajian ini menunjukkan bahwa kompetisi terhadap unsur $\mathrm{Fe}^{3+}$ menjadi salah satu mekanisme antibiosis $P$. fluorescens dan $P$. aeruginosa terhadap jamur $R$. lignosus.

\section{SIMPULAN}

Dua isolat bakteri dalam penelitian ini yaitu $P$. fluorescens dan $P$. aeruginosa merupakan jenis bakteri dari kelompok Pseudomonads pendarfluor yang menghasilkan pigmen pendarfluor yang bersifat antibiosis terhadap R. lignosus. Aktivitas antibiosis pigmen pendarfluor dipengaruhi oleh $\mathrm{kadar} \mathrm{Fe}^{3+}$, ini menunjukkan bahwa antibiosis isolat bakteri uji terkait dengan pengeluaran siderofor sebagai bahan kelat yang dapat mengikat unsur $\mathrm{Fe}^{3+}$. Uji affinitas pada spektrofotometer memperlihatkan bahwa siderofor yang dihasilkan $P$. fluorescens dan $P$. aeruginosa termasuk siderofor golongan katekol yang lebih kuat mengikat unsur $\mathrm{Fe}^{3+}$ dibandingkan siderofor golongan hidroksamat yang 
umumnya dihasilkan jamur. Dengan demikian kompetisi terhadap unsur $\mathrm{Fe}^{3+}$ merupakan mekanisme antagonis
P. fluorescens dan P. aeruginosa terhadap R. lignosus.

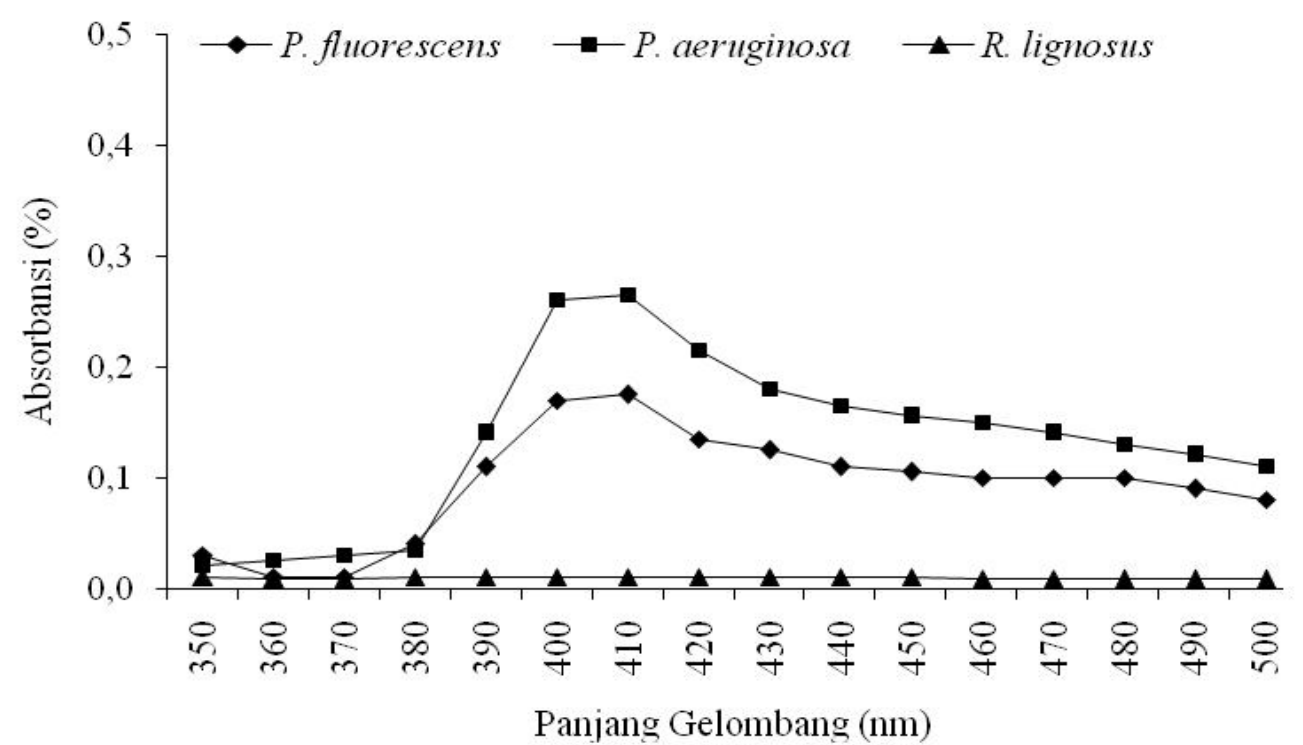

Gambar 1. Puncak absorbansi pigmen pendarfluor dari supernatan media biakan bakteri $P$. fluorescens, $P$. aeruginosa dan jamur $R$. lignosus pada Spektrofotometer 350-500 nm.

\section{DAFTAR PUSTAKA}

Basuki. 1985. Efforts in the control of WRD (R.1) of rubber in Indonesia. Pp: 209-221 In: Rubber Research Institue of Malaysia, Procedings International Rubber Conference, Kuala Lumpur Malaysia, October, 21-25, 1985.

Cui X \& Harling R, 2006. Evaluation of bacterial antagonists for biological control of broccoli head rot caused by Pseudomonas fluorescens. Phytopathology 96(5): 408-416.

de Souza JT, Arnould C, Deulvot C, Lemanceau P, Gianinazzi-Pearson V \& Raaijmakers JM. 2003. Effect of 2,4-diacetylphloroglucinol on Pythium: Cellular responses and variation in sensitivity among propagules and species. Phytopathology 93(8): 966-975.

Duijff BJ, Bakker PAHM \& Schipper B. 1994. Suppression of Fusarium wilt of carnation by Pseudomonas putida WCS358 at different levels of disease incidence and iron availability. Biocontrol Sci. Technol. 4(3): 279-288.

Goszczynska T, Botha WJ, Venter SN \& Coutinho TA. 2007. Isolation and identification of the causal agent of brown stalk rot, a new disease of maize in South Africa. Plant Dis. 91(6): 711-718.

Gould WD, Hagedorn C, Bardinelli TR \& Zablotowicz RM. 1985. New selective media for enumeration and recovery of Fluorescent Pseudomonads from various habitat. Appl. And Environ. Microbiol. 49(1): 28-32.

Haas D \& Défago G. 2005. Biological control of soilborne pathogens by fluorescent pseudomonads. Nat. Rev. Microbiol. 3(4): 307-319.

Humphris SN, Bengough AG, Griffiths BS, Kilham K, Rodger S, Stubbs V, Valentine TA \& Young IM. 2005. Root cap influences root colonisation by Pseudomonas fluorescens SBW25 on maize. FEMS Microbiol. Ecol. 54(1): 123-130.

Jean-Marie Meyer, Valérie AG, Nader B, Louis G, Daniel I, Philippe L, Wafa A \& Norberto JP. 2002. Siderophore typing, a powerful tool for the identification of fluorescent and nonfluorescent Pseudomonads. Appl. And Environ. Microbiol. 68(6): 2745-2753.

Kado CI \& Heskett MG. 1970. Selective media for isolation of Agrobacterium, 
Corynebacterium, Erwinia, Pseudomonas, and Xanthomonas. Phytopathology. 60(6): 969976.

Kloepper JW. 1993. Plant growth-promoting rhizobacteria as biological control agents. Pp. 255-274 In: Metting FB, ed. Soil Microbial Ecology: Applications in Agricultural and Environmental Management. Marcel Dekker Inc., New York.

Loper JE, Kobayashi DY \& Paulsen IT. 2007. The genomic sequence of Pseudomonas fluorescens Pf-5: Insights into biological control. Phytopathology. 97(2): 233-238.

Mavrodi DV, Ian TP, Qinghu Ren \& Joyce EL. 2007. Genomics of Pseudomonas Fluorescens PF5. Pp. 3-30 In: Juan-L. R. \& Alain F. eds. Pseudomonas "A Model System in Biology". Springer, NY

Meyer JM \& Abdallah MA. 1978. The fluorescent pigmen of Pseudomonas fluorescens: Biosynthesis, purification and physicochemical properties. J. Gen. Microbiol. 107(2): 319-328.

Michel L, Gonzalez N, Jagdeep S, Nguyen-Ngoc T \& Reimmann C. 2005. PchR-box recognition by the AraC-type regulator PchR of Pseudomonas aeruginosa requires the siderophore pyochelin as an effector. Mol. Microbiol. 58(2): 495509 .

Neilands JB \& Leong SA, 1986. Siderophores in relation to plant growth and disease. Ann. Rev. Plant. Physiol. 37(6): 187-208.

Powell JF, Vargas JM Jr, Nair MG, Detweiler AR \& Chandra A. 2000. Management of dollar spot on creeping bentgrass with metabolites of Pseudomonas aureofaciens (TX-1). Plant Dis. 84(1): 19-24.

Press CM, Loper JE \& Kloepper JW. 2001. Role of iron in rhizobacteria-mediated induced systemic resistance of cucumber. Phytopathology. 91(6): 593-598.
Raaijmakers JM, de Bruijn I \& de Kock MJ. 2006. Cyclic lipopeptide production by plant-associated Pseudomonas spp.: diversity, activity, biosynthesis, and regulation. Mol. PlantMicrobe Interact. 19(7): 699-710.

Scher FM \& Baker R. 1982. Effect of Pseudomonas putida and a synthetic iron chelator on indction of soil suppressiveness to Fusarium wilt pathogens. Phytopathology. 72(12): 15671573.

Sebat JL, Paszczynski AJ, Cortese MS \& Crawford RL. 2001. Antimicrobial properties of pyridine2,6-dithiocarboxylic acid, a metal chelator produced by Pseudomonas spp. Appl Environ Microbiol. 67(9): 3934-3942.

Stockwell VO \& Stack JP. 2007. Using Pseudomonas spp. for integrated biological control. Phytopathology. 97(2): 244-249.

Stutz EW, Defago G \& Kern H. 1986. Naturally occurring fluorescent pseudomonads involved in suppression of black root rot of tobacco. Phytopathology. 76(2): 181-185

Teintze M, Hossain MB, Baines CL, Leong J \& van der Helm D. 1981. Structure of ferric pseudobactin, a siderophore from a plant growth promoting Pseudomonas. Biochemistry 20(22): 6446-6457.

Temple TN, Stockwell VO, Loper JE \& Johnson KB. 2004. Bioavailability of iron to Pseudomonas fluorescens A506 on flowers of pear and apple. Phytopathology. 94(12): 1286-1294.

Weller DM. 2007. Pseudomonas biocontrol agents of soilborne pathogens: Looking back over 30 years. Phytopathology. 97(2): 250-256.

Weller DM, Raaijmakers JM, McSpadden Gardener BB \& Thomashow LS. 2002. Microbial populations responsible for specific soil suppressiveness to plant pathogens. Annu. Rev. Phytopathol. 40(1):309-348. 